Food, Dairy and Home Economic Research

http:/www.journals.zu.edu.eg/journalDisplay.aspx?Journalld=1\&queryType=Master

\title{
EFFECT OF FROZEN STORAGE ON THE QUALITY ATTRIBUTES OF FRESH AND CONCENTRATE CUT-BACK STRAWBERRY JUICES
}

\author{
Fathi M.M. Fathi", M. Ragab, H.A.I. Siliha and A.M. Sulieman \\ Food Sci. Dept., Fac. Agric., Zagazig Univ., Egypt
}

Received: 10/07/2019; Accepted: 04/08/2019

\begin{abstract}
The present study was aimed to evaluate the effect of frozen storage at $-18^{\circ} \mathrm{C}$ for 6 months on the quality attributes of the fresh and the concentrate Cut-back strawberry juices. The obtained results showed that the concentrate Cut-back strawberry juice was more acceptable by panelists. A significant decline in titratable acidity after freezing was observed in both types of strawberry juices; it decreased from 0.85 to 0.41 and from 0.98 to $0.49 \%$ for fresh strawberry juice and concentrate Cut-back juice, respectively. After 6 months of frozen storage similar tendency was observed for their vitamin C content having 9.45 and $29.23 \mathrm{mg} / 100 \mathrm{ml}$ for fresh and concentrate Cutback strawberry juice, respectively. The $\mathrm{pH}$ increased from 3.805 to 4.340 and from 3.604 to 4.252 for fresh strawberry juice and concentrate Cut-back juice, respectively. The concentrated Cut-back strawberry juice prior to freezing was found to be rich in ferulic acid, resorcinol and quercetin being $10.09,0.24$ and $731.98 \mathrm{ppm}$ which were by respectively compared to fresh strawberry juice. Quercetin was the dominant compound, it was the only one that found in the two juices after 6 months of frozen storage. While, kaempherol was appeared after freezing for the two types of juices and showed gradual increase by increasing the duration of frozen storage. The Cut-back strawberry juice showed higher antioxidant activity and viscosity than fresh juice. A slight decrease in viscosity was observed for the two types of juice after storage at $-18^{\circ} \mathrm{C}$ for 6 months. The colour was not stable during the frozen storage at $-18^{\circ} \mathrm{C}$, The colour values increased in fresh strawberry juice for $\mathrm{L}^{*}, \mathrm{a}^{*}$ and $\mathrm{b}^{*}$ from 12.73, 21.00 and 7.77 to $16.89,25.94$ and 9.91, respectively, but in Cut-back strawberry juice the value of $\mathrm{L}^{*}$ was only increased from 13.23 to13.55 while, $\mathrm{a}^{*}$ and $\mathrm{b}^{*}$ values decreased from 25.75 and 8.11 to 22.68 and 7.00 , respectively. From results, it could be concluded that the Cut-back strawberry juice had the best quality after 6 months of frozen storage.
\end{abstract}

Key words: Strawberry juice, Cut-back, freezing, Vitamin C, antioxidant activity, colour, viscosity

\section{INTRODUCTION}

Strawberry (Fragaria ananassa) is an important fruit. It is an attractive fruit and widely appreciated by the consumers because of its appealing fruity flavour particularly sweetness and aroma, bright red colour and juicy texture. Nutritionally, strawberry contains low calorie and a potential source of vitamin $\mathrm{C}$, fibers and provides more vitamin $\mathrm{C}$ than oranges (Wisal et al., 2014). The main constituents in $100 \mathrm{~g}$ of the fruit are vitamin C $(64.0 \mathrm{mg})$, water $(91.75 \mathrm{~g})$, protein $(0.61 \mathrm{~g})$, fat $(0.37 \mathrm{~g})$, carbohydrate $(7.02 \mathrm{~g})$, fibre $(2.3 \mathrm{~g})$, calcium
(14.0 mg), potassium $(103.75 \mathrm{mg})$ and vitaminA $(27 \mathrm{IU})$. The $\mathrm{pH}$ value ranges from 3.27 to 3.86, which help in stabilizing colour (Wisal et al.,2014). Acidity range is between 0.58 and $1.35 \%$ calculated as citric acid. Citric and malic acids are primary organic acids contributing excellent flavour. Soluble solids are in the range of $8.0-11.5 \%$ and are ideal for juice concentrate needed in the market. Soluble solids: acid ratio is 8.52: 13.79 given good balance of sweet-tart flavour (Ayub et al., 2010). The red colour of the fruit is due to presence of an anthocyanin, pelargonidin 3-monoglucosides, and traces of cyaniding. Strawberries have high level of

\footnotetext{
*Corresponding author: Tel. : +201033912952

E-mail address: eng.fathibekhat2010@yahoo.com
} 
antioxidant compounds that provide the protection against harmful free radicals (Zheng et al., 2007) and can be considered as a functional food because they contain biologically active compounds that provide clinically proven health benefits for the prevention, management or treatment of diseases (Singh et al., 2011; Skrovankova et al., 2015).

Strawberry can be consumed in fresh or processed form such as preserved fruit juice. But, due to the seasonality of the strawberry, the fresh fruits are only available for few months per year. In order to overcome this seasonality, the fresh fruits are preserved by freezing and it is one of the best options to preserve such fruits. So, the frozen strawberry can be used in the production of attractive products through the year (Chandra and Kumari, 2015) such as pies, tart, strawberry juice, concentrate, puree, milkshake, jam and in the production of red wine alone or in combination with other fruits (El Samh et al., 2013). Strawberries are well known for their extensive flavour and are widely used to prepare juices (Bood and Zabetakis, 2002). Fruit juice concentrates are produced by a freeze concentration, low temperature vacum evaporation, high speed high temperature evaporation and reverse osmosis. In the last decade there has been considerable increase in demand for a strawberry juice because it possesses an excellent flavour with attractive colour. However, being a soft Textured fruit, a little fluctuation in a temperature results in spoilage and wastage of fruit.

Due to lack of other preservation facilities to preserve the product in raw form, this study has been conducted to utilize the very perishable fruit in the form of juice concentrates and to study the effect of cut back process and freezing at $-18^{\circ} \mathrm{C}$ for 6 months on quality attributes of the end product. To achieve these goals, a concentrate of strawberry juice was prepared using rotary evaporator, the Cut-back technique was used in the preparation of strawberry juice from the concentrate and the obtained juice was compared with fresh one in terms of sensory quality attributes, chemical and physical characteristics during freezing at $-18^{\circ} \mathrm{C}$ for 6 months.

\section{MATERIALS AND METHODS}

\section{Materials}

Fully ripe red strawberry fruits (Fragaria ananassa Duch, cultivar Fortuna) were purchased in March from a local Farm in Mashtool El-Souk, Sharkia Government, Egypt. $50 \mathrm{Kg}$ strawberry fruits were washed by tap water and the caly, sand and non-edible parts were removed, then the fruits were packed in airtight polyethylene bags and stored at $-18^{\circ} \mathrm{C}$ until their use.

\section{Methods}

\section{Preparation of fresh and concentrated strawberry juices}

Strawberry juice $\left(6.2^{\circ}\right.$ Brix) was obtained using domestic juice extractor (Kenwood, KHH326WH MultiOne, $1000 \mathrm{~W})$. To obtain the concentrated juice $\left(30^{\circ}\right.$ Brix), the water was evaporated using rotary evaporator (BuchiRotavapor R-124 Rotary Evaporator, Switzerland). Preliminary trial was carried out at different temperatures: 30,40 and $50^{\circ} \mathrm{C}$, in order to optimize the operating conditions and to obtain a strawberry concentrate with acceptable sensory quality in terms of colour and flavour. The temperature of $40^{\circ} \mathrm{C}$ was the optimum one according to the preliminary sensory evaluation results (Nistor et al., 2010).

\section{Preparation of cut-back strawberry juice}

The Cut-back strawberry juice $\left(22.3^{\circ}\right.$ Brix $)$ was prepared from concentrated strawberry juice $\left(30^{\circ}\right.$ Brix), by adding fresh strawberry to concentrated one with a ratio of $1: 2(V / V)$, respectively.

\section{Frozen storage of fresh and cut-back strawberry juices}

The fresh and Cut-back strawberry juices were packed in plastic jars $(330 \mathrm{ml})$ and stored in a freezer at $-18^{\circ} \mathrm{C}$ for six months.

Various assessments and characterizations were carried out monthly during the six months of frozen storage for the two types of strawberry juices; fresh and Cut-back, as previously described; except the sensory evaluation, flavonoids and phenolic acids determinations were carried out only 3 times; directly after preparation, after 3 months and at the end of frozen storage after 6 months. 


\section{Sensory evaluation}

The frozen fresh and Cut-back strawberry juices were submitted to their sensory evaluation. In order to evaluate the sensorial characteristics of Cut-back strawberry juice, $260 \mathrm{ml}$ of distilled water was added to $100 \mathrm{ml}$ Cut-back strawberry juice to get $6.2^{\circ}$ as Brix of fresh strawberry juice. Sensory evaluation was conducted by using the score sheet according to (Vranac et al., 2017). The panelists $(\mathrm{n}=10)$ were asked to score flavour, odour, texture, colour and appearance of strawberry juices; each was judged on a scale from 1 (extremely dislike) to 5 (extremely like) grade as a score for each of strawberry juice

\section{Titratable acidity and $\mathrm{pH}$ determination}

Titratable acidity of fresh and Cut-back strawberry juices were determined using the titration with $0.1 \mathrm{M}$ sodium hydroxide solution to $\mathrm{pH}=8.2$ as an end point using $\mathrm{pH}$ meter (model 646 Digital, USA) at room temperature. The acidity was expressed as citric acid (SI Analytics, 2012). The $\mathrm{pH}$ values of the two strawberry juices were measured using the aforementioned $\mathrm{pH}$ meter at the same room temperature.

\section{Vitamin $\mathbf{C}$ determination}

Vitamin $\mathrm{C}$ of fresh and Cut-back strawberry juices was determined according to Rangana (1977) which is based on the reduction of 2,6 dichlorophenol indophenol dye by ascorbic acid.

Antioxidant activity, flavonoids and phenolic acids determination

Antioxidant activity of strawberry juices was evaluated as free radical scavenging activity by DPPH as described by Su and Silva (2006) and expressed as per cent of antiradical activity against DPPH. Flavonoids and phenolic acids contents in fresh and Cut-back strawberry juices were determined using HPLC (The system Thermo (Ultimate 3000) consisted of: pump, automatic sample injector, and associated DELL-compatible computer supported with Cromelion7 interpretation program) according to Biswas et al. (2013).

\section{Colour}

The colour of fresh and Cut-back strawberry juices was determined using a Hunter Lab
(Colour Flex EZ Spectrophotometer, USA) according to Granato and Masson (2010). The apparatus was calibrated with a white and black standard tile using the CIE scale L* $\mathrm{a}^{*} \mathrm{~b}$ * before running the measurement. Samples were placed in the standard cup and the colour values were recorded and expressed as $L^{*}(0$ : black, 100: white), $a^{*}\left(-a^{*}\right.$ : greenness, $+a^{*}$ : redness), and $b^{*}$ (-b*: blueness, $+b^{*}$ : yellowness).

\section{Viscosity}

The viscosity of fresh and Cut-back strawberry juices were carried out using the Brookfield rotational viscometer (model DV-I+ Viscometer, LV version 4.1, USA) using spindle No.4 for fresh juices and spindle No.1 for Cut-back strawberry juices at $60 \mathrm{rpm}$ at $25^{\circ} \mathrm{C}$ (Bukurov et al, 2012).

\section{Statistical Analysis}

An ANOVA was performed by the General Linear Models using SPSS 22.0 package program (SPSS Inc., Chicago, IL), and LSD test was used to find significant differences ( $P$ $<0.05)$ (McClave and Benson, 1991).

\section{RESULTS AND DISCUSSION}

\section{Sensory Evaluation}

Table 1 shows the mean score values of sensory evaluation of both fresh and Cut-back strawberry juices. The evaluation was performed at zero time (directly after preparation), after 3 months and after 6 months of frozen storage.

As general tendency, it could be noticed that the freezing process had a negative effect on the sensory characteristics of both fresh and concentrate Cut-back strawberry juices; whereas, all the quality attributes decreased during the frozen storage especially odour, colour and texture of concentrate Cut-back strawberry juice after 6 months. These decreased may be attributed to enzymatic activity such as peroxidase, lipoxygenase, catalase, polyphenol oxidase, and pectin methylesterase. However, peroxidase activity does not diminish strawberry juices quality under freezing conditions, by reason of the freezing process is thought to increase the solubility of some peroxidase fractions that are attached to cell membranes (Cano et al., 1998). 
Table 1. Sensory evaluation of fresh and reconstituted Cut-back strawberry juices during frozen storage at $-18^{\circ} \mathrm{C}$

\begin{tabular}{|c|c|c|c|c|c|c|}
\hline Sensory properties & \multicolumn{2}{|c|}{ Zero-time } & \multicolumn{2}{|c|}{ After 3 months } & \multicolumn{2}{|c|}{ After 6 months } \\
\hline Sample & Fresh & Cut-back & Fresh & Cut-back & Fresh & Cut-back \\
\hline$\overline{\text { Flavour (5) }}$ & $4.20^{\mathrm{a}}$ & $4.10^{\mathrm{ab}}$ & $4.00^{\mathrm{bc}}$ & $4.00^{\mathrm{bc}}$ & $3.80^{\mathrm{d}}$ & $3.90^{\text {cd }}$ \\
\hline Odour (5) & $3.80^{\mathrm{a}}$ & $3.81^{\mathrm{a}}$ & $3.60^{\mathrm{b}}$ & $3.72^{\mathrm{ab}}$ & $3.40^{\mathrm{c}}$ & $3.70^{\mathrm{ab}}$ \\
\hline Colour (5) & $4.20^{\mathrm{a}}$ & $4.20^{\mathrm{a}}$ & $4.00^{\mathrm{a}}$ & $4.00^{\mathrm{a}}$ & $3.50^{\mathrm{b}}$ & $4.00^{\mathrm{a}}$ \\
\hline Texture (5) & $4.00^{\mathrm{a}}$ & $4.18^{\mathrm{a}}$ & $3.90^{\mathrm{ab}}$ & $4.00^{\mathrm{a}}$ & $3.81^{\mathrm{b}}$ & $4.00^{\mathrm{a}}$ \\
\hline Appearance (5) & $3.90^{\mathrm{a}}$ & $4.00^{\mathrm{a}}$ & $3.90^{\mathrm{a}}$ & $4.00^{\mathrm{a}}$ & $3.60^{\mathrm{b}}$ & $3.90^{\mathrm{a}}$ \\
\hline Overall acceptability (\%) & $80.4 \%$ & $81.2 \%$ & $77.6 \%$ & $78.8 \%$ & $72.4 \%$ & $78.0 \%$ \\
\hline
\end{tabular}

Others factors such as changes in $\mathrm{pH}$, water activity, temperature and length of frozen storage could have contributed to the degradation of pigments (Bonat Celli et al., 2016). Whatever, the case may be, at the duration of frozen storage, the concentrate Cut-back strawberry juice was the most preferable than fresh strawberry juice having an overall acceptability score of $78 \%$ versus $72.4 \%$ for fresh juice (Table 1).

\section{Titratable Acidity and pH}

The titratable acidity and $\mathrm{pH}$ value of fresh and concentrate Cut-back strawberry juices during frozen storage are shown in Fig. 1. The obtained results showed significant decline in the titratable acidity during the frozen storage of the two types of strawberry juice. It was decreased from 0.85 to 0.41 and from 0.98 to 0.49 for fresh strawberry juice and concentrate Cut-back juice, respectively, while the $\mathrm{pH}$ values increased from 3.805 to 4.340 and from 3.604 to 4.252 for fresh strawberry juice and concentrate Cut-back juice, respectively. The decreasing in titratable acidity and increasing the $\mathrm{pH}$ value could be explained by increasing the content of alcoholic compounds during the storage. These findings agree with those of Forney et al. (2000) and Ayub et al. (2010).

\section{Vitamin C}

Fig. 2 shows vitamin $\mathrm{C}$ content of fresh and concentrate Cut-back strawberry juices. The juices varied in their values of vitamin $\mathrm{C}$ retention during the frozen storage at $-18^{\circ} \mathrm{C}$. The obtained results revealed a loss in vitamin $\mathrm{C}$ for the two types of juice; it decreased by about 53 and $36 \%$ for fresh and concentrate Cut-back strawberry juices after freezing for 6 months, respectively. So, vitamin C loss was more remarkable in fresh strawberry than the concentrate Cut-back one. Sahari et al. (2004) reported that ascorbic acid level decreases with time and with loss of $33-55 \%$ at the end of one year frozen storage. In general, losses of ascorbic acid resulted thorough freezing process may differ within the range from 10 to $80 \%$, with an average rate of $50 \%$ (Rickman et al., 2007). The loss in vitamin $C$ may be related to oxidation of ascorbic acid during storage. The oxidation of ascorbic acid may be enzymic or nonenzymic. The enzyme that mainly cause the loss of vitamin $\mathrm{C}$ is ascorbate oxidase. If this enzyme is not inactivated by pretreatments, it keeps its activity during the frozen storage of the product (Hui et al., 2011). The obtained results are in agreement with those obtained by Sapei and Hwa (2014); Sheraz et al. (2015).

\section{Phenolic Acids and Flavonoids Content and Antioxidant Activity}

Table 2 illustrates the phenolic acids and flavonoids contents in fresh and concentrate Cut-back strawberry juice during frozen storage. The obtained results showed that the concentrate Cut-back strawberry juice (prior to freezing) was rich in ferulic acid, resorcinol and quercetin reflecting higher values than those of fresh 

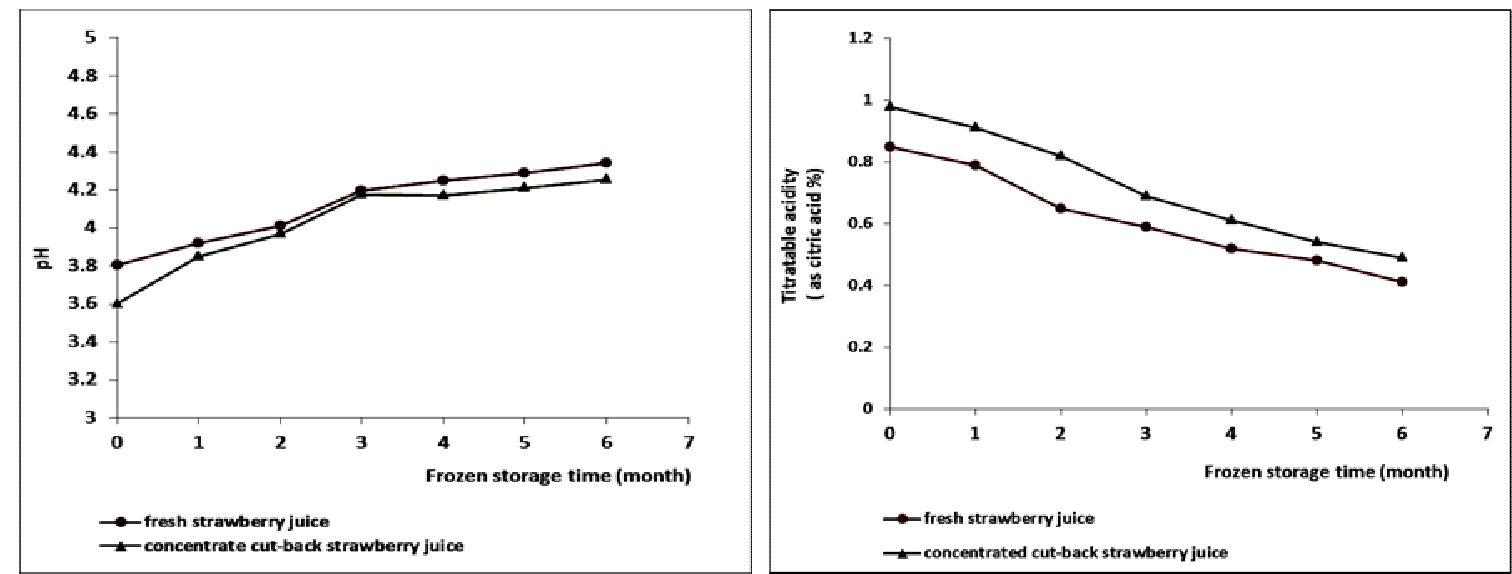

Fig. 1. Titratable acidity as citric acid (\%) and $\mathrm{pH}$ of fresh and concentrate Cut-back strawberry juices during frozen storage at $-18^{\circ} \mathrm{C}$

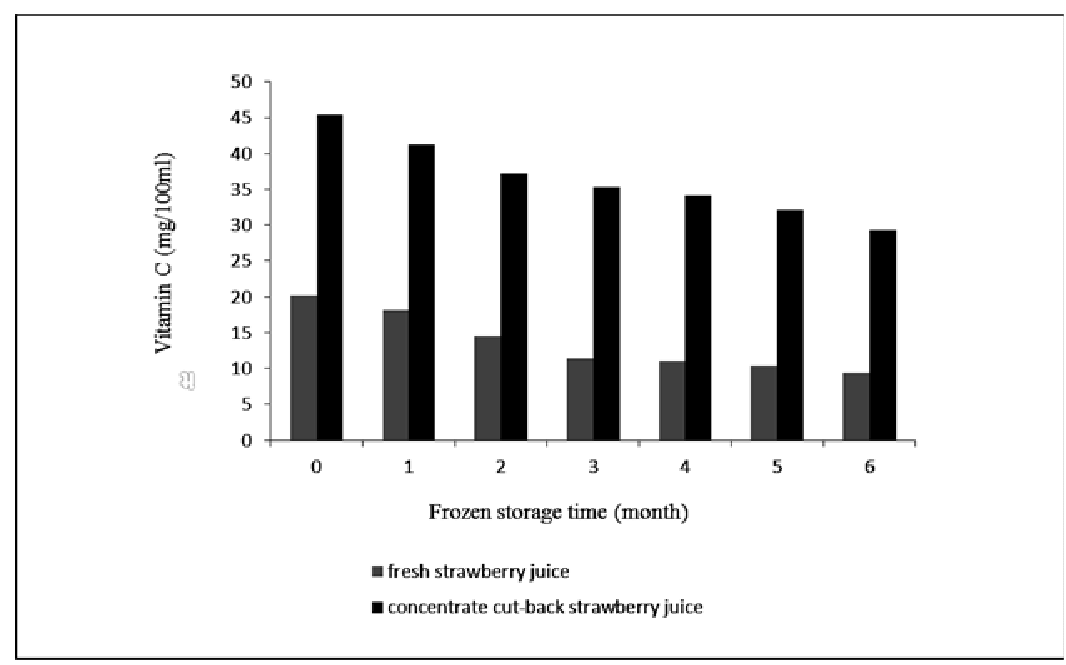

Fig. 2. Vitamin $C$ content of fresh and concentrate Cut-back strawberry juices during frozen storage at $-18^{\circ} \mathrm{C}$.

Table 2. Phenolic acids and flavonoids contents (ppm) extracted from fresh and concentrate Cut-back strawberry juices during frozen storage at $-18^{\circ} \mathrm{C}$

\begin{tabular}{lcccccc}
\hline Compound & \multicolumn{2}{c}{ Zero time } & \multicolumn{2}{c}{ 3 months } & \multicolumn{2}{c}{ 6 months } \\
\cline { 2 - 7 } \multicolumn{1}{c}{ Storage time } & Fresh & Cut-back & Fresh & Cut-back & Fresh & Cut-back \\
\hline Ferulic acid & 4.1668 & 10.0884 & ND & ND & ND & ND \\
Resorcinol & 0.0652 & 0.2404 & ND & ND & ND. & ND \\
Quercetin & 615.7831 & 731.9814 & 354.1582 & 338.9551 & 450.7553 & 305.9836 \\
Kaempherol & ND & ND & 540.2301 & 668.4359 & 519.0599 & 632.8034 \\
\hline
\end{tabular}

ND: Non detected 
strawberry juice. Quercetin was decreased by 42.5 and $53.7 \%$ after freezing for 3 months and by 26.8 and $58.2 \%$ after freezing for 6 months for fresh and concentrate Cut-back strawberry juices, respectively. It is worth to mention here that kaempherol compound was appeared after freezing the two types of juices, its content was higher in concentrate Cut-back strawberry juice by about 23.7 and $21.9 \%$ than those of fresh strawberry juice after 3 and 6 months, respectively. (Table 2). The decrease of ferulic acid, resorcinol and quercetin may due to enzymatic activity of polyphenol oxidase (Chaovanalikit and Wrolstad, 2004) while, the increase in kaempherol content in the two types of strawberry juices may be related to a hydrolysis and transformation processes of some flavonoid compounds.

Fig. 3 shows the antioxidant activity of fresh and concentrate Cut-back strawberry juices. The obtained results showed that the concentrate Cut-back strawberry juice had higher antioxidant activity than fresh juice even after freezing. The initial antioxidant activity before freezing was higher by about $166 \%$ and $328 \%$ for the final antioxidant activity after 6 months of freezing at $-18^{\circ} \mathrm{C}$ when compared to fresh strawberry juice. The high antioxidant activity of concentrate Cutback strawberry juice could be attributed to its higher content of vitamin $\mathrm{C}$ and phenolic compounds such as flavonoids and phenolic acids than fresh juice. A gradual reduction in antioxidant activity was also observed during frozen storage for the two types of strawberry juices, it decreased by about 45.4 and $12.0 \%$, respectively for fresh and concentrate Cut-back strawberry juice after 6 months of freezing at $18^{\circ} \mathrm{C}$. This reduction in antioxidant activity after freezing may be due to the oxidation of some phenolic compounds by polyphenol oxidase and transformation to other compounds. These observation are in line with those of Lee $\boldsymbol{e t}$ al. (2003), Muller et al. (2010) and Gurel et al. (2018).

\section{Colour}

Fig. $4 \mathrm{a}, \mathrm{b}$ and c illustrate the colour parameters $L^{*}, a^{*}$ and $b^{*}$ of fresh and concentrate Cut-back strawberry juices during frozen storage at $18^{\circ} \mathrm{C}$.The obtained results showed a gradual increase in $\mathrm{L}^{*}$ of fresh strawberry juice during frozen storage by about $32.6 \%$ at the end of frozen storage after 6 months. While, the $\mathrm{L}^{*}$ value of concentrate Cut-back strawberry juice was almost constant during frozen storage at $18^{\circ} \mathrm{C}$. Slightly increase in $\mathrm{a}^{*}$ and $\mathrm{b}^{*}$ values for concentrate Cut-back strawberry juice compared with fresh strawberry juice. The colour was highly unstable during long-term frozen storage because the serious colour changes that occurred. These changes in the two types of strawberry juice can be explained by the conversion of monomeric form of anthocyanins to polymeric form reducing the colour intensity; also the developing of brown colour which not hastened destruction of red colour concerning the $b^{*}$ value in the case of fresh strawberry juice. These obtained results are in harmony with those of Poiana et al. (2010) and Sriwattana et al. (2015).

\section{Viscosity}

Fig. 5 shows the viscosity of fresh and concentrate Cut-back strawberry juices. The concentrate cut back strawberry juice was more viscous than the fresh juice. This was due to the concentration process where the Brix degree of concentrate Cut-back strawberry juice was higher than fresh juice reflecting the high soluble solids content; $22.3^{\circ}$ versus $6.2^{\circ}$. The freezing time caused a slight effect on the juice consistency. The obtained results showed nonpronounced decrease in the viscosity of the two types of strawberry juices and this could be explained by the decrease of pectin fraction through the chemical and enzymatic modifications which can interfere with juice quality as reported by Lisiewska and Kmiecik (2000).

\section{Conclusion}

The freezing time had significant impact on chemical and physical properties for both types of strawberry juices, however the concentrate Cut-back strawberry was the best for all chemical and physical properties during freezing storage for 6 months, it was more acceptable compared to fresh juice by panelists. So, concentration process maintain the quality attributes of the juice during freezing storage not more than 3 months. 
Zagazig J. Agric. Res., Vol. 46 No. (5) 2019

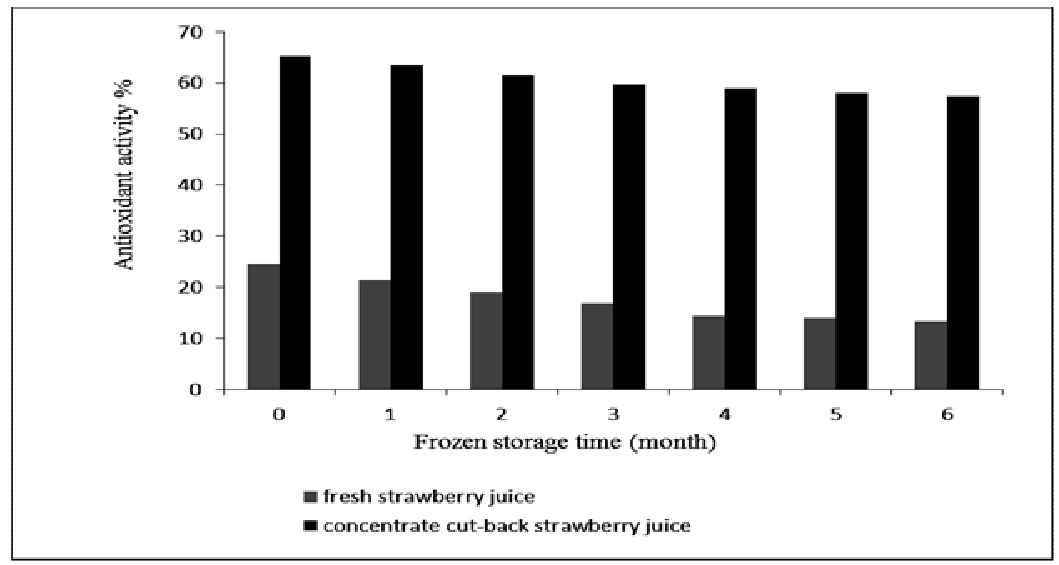

Fig. 3. Antioxidant activity of fresh and concentrate Cut-back strawberry juices during frozen storage at $-\mathbf{1 8}^{\circ} \mathrm{C}$
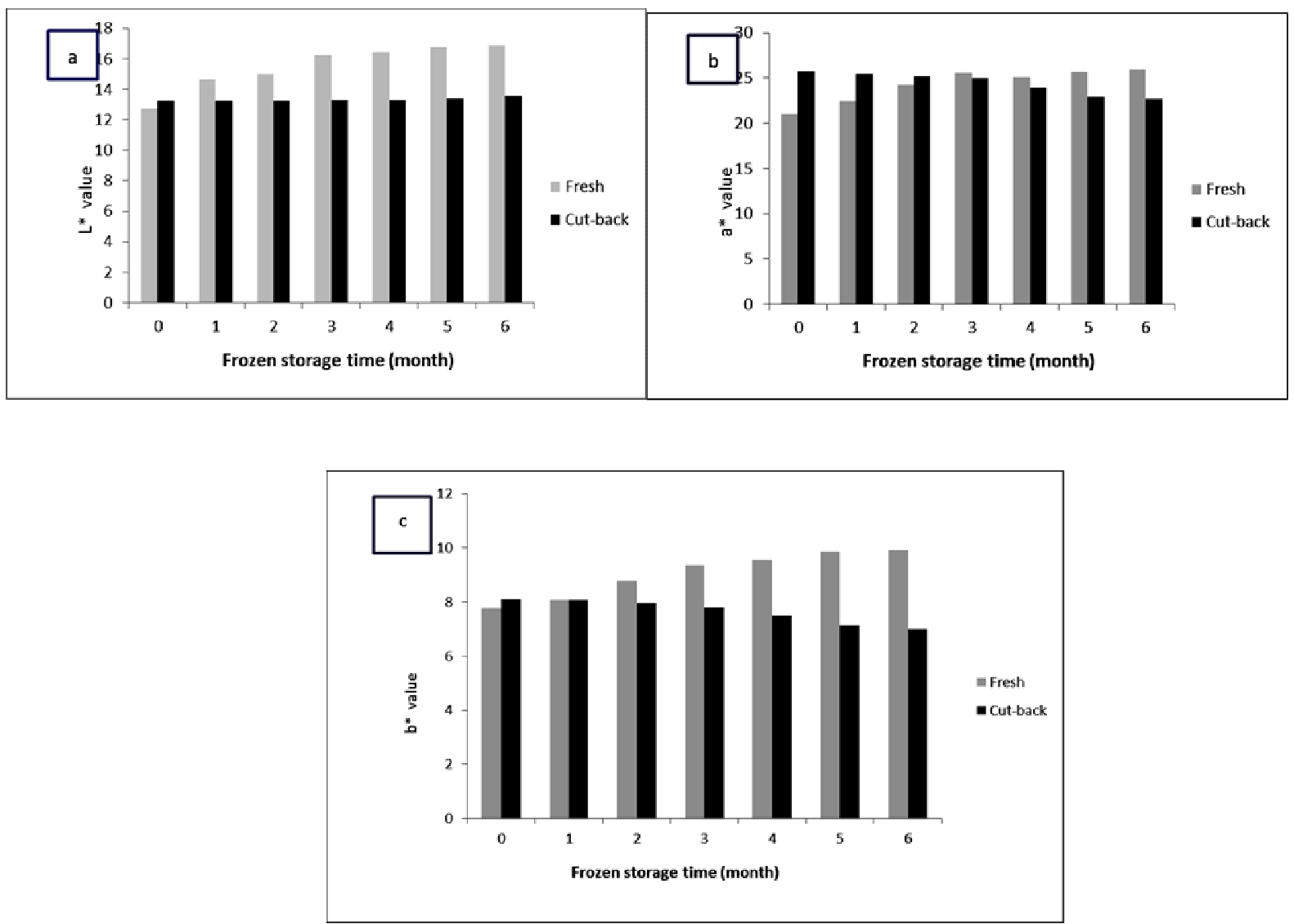

Fig. 4. Colour parameters; $L^{*}, a^{*}$ and $b^{*}$ of fresh and concentrate Cut-back strawberry juices during frozen Storage at $-18^{\circ} \mathrm{C}$ 


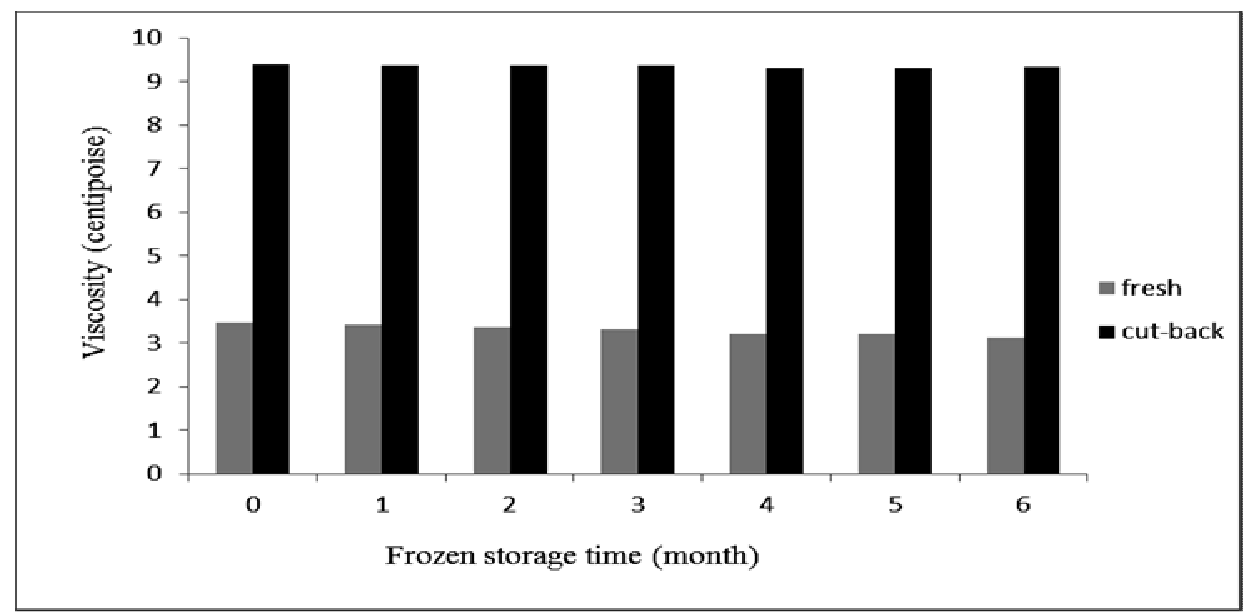

Fig. 5. Viscosity of fresh and concentrate Cut-back strawberry juices during frozen Storage at $18^{\circ} \mathrm{C}$

\section{REFERENCES}

Ayub, M., J. Ullah, A. Muhammad and A. Zeb (2010). Evaluation of strawberry juice preserved with chemical preservatives at refrigeration temperature. Int. J. Nutr. and Metabolism, 2 (2): 027-032.

Biswas, N., P. Balac, S.K. Narlakanti, K. Haque, M.D. Enamul and M.D.H. Mehedi (2013). Identification of phenolic compounds in processed cranberries by HPLC Method. Nutr. Food Sci., 3 (1):1-6. doi:10.4172/21559600.1000181.

Bonat Celli, G., A. Ghanem and M. Su-Ling Brooks (2016). Influence of freezing process and frozen storage on the quality of fruits and fruit products. Food Rev. Int., 32 (3): 280304.

Bood, K.G. and I. Zabetakis (2002). The biosynthesis of strawberry flavour (II): Biosynthetic and molecular biology studies. J. Food Sci., 67 (1) : 2-8.

Bukurov, M., S. Bikić, M. Babić, I. Pavkov and M. Radojčin (2012). Rheological behavior of SengaSengana strawberry mash. J. Proc. and Energy in Agric., 16 (4): 142 - 146.

Cano, M.P., M.G. Lobo and B. De Ancos (1998). Peroxidase and polyphenol oxidase in longterm frozen stored papaya slices. Differences among hermaphrodite and female papaya fruits. J. Sci. Food Agric., 76 (1):135-141.

Chandra, S. and D. Kumari (2015). Recent development in osmotic dehydration of fruit and vegetables: A review. Critical Rev. Food Sci. and Nutr., 55 (4): 552-561.

Chaovanalikit, A. and R.E. Wrolstad (2004). Anthocyanin and polyphenolic composition of fresh and processed cherries. J. Food Sci., 69 (1): 73-83.

El-Samh, M.M.A., A.A.D. Sherein and H.H. Essam (2013). Properties and antioxident activity of probiotic yoghurt flavoured with black carrot, pumpkin and strawberry. Int. J. Dairy Sci., 8 (2): 48-57.

Forney, C.F., W. Kalt and M.A. Jordan (2000). The composition of strawberry aroma is influenced by cultivar, maturity and storage. Hort. Sci., 35 (6): 1022-1026.

Granato, D. and M.L. Masson (2010). Instrumental colour and sensory acceptance of soy-based emulsions: a response surface approach. Food Sci. and Technol., 30 (4): $1090-1096$.

Gurel, D.B., D. Kart, O. Cagindi and N. Bagdatlioglu (2018). Determination of antioxidant activity and total anthocyanin content of frozen and thawed strawberries under different conditions. Int. J. Innovative 
Approaches in Agric. Res., 2 (3): 177-186. doi: 10.29329/ijiaar.2018.151.4

Hui, Y.H., N.K. Sinha, E.Ö. Evranuz, M. Sıddıq and J. Ahmed (2011). Handbook of Vegetables and Vegetable Processing. Wiley-Blackwell, Ltd, 2121 State Avenue, Ames, Iowa, USA.

Lee, K.W., Y.J. Kim, D.O. Kim, H.J. Lee and C.Y. Lee (2003). Major phenolics in apple and their contribution to the total antioxidant capacity. J. Agric. Food Chem., 51 (22): $6516-6520$.

Lisiewska, Z. and W. Kmiecik (2000). Effect of storage period and temperature on the chemical composition and organolectic quality of frozen tomato cubes. Food Chem., 70 (2): 167-173.

McClave, J. and G. Benson (1991). Statistics for Business and Economics. Dellen Publishing, $5^{\text {th }}$ Ed. San Francisco, USA.

Müller, L., S. Gnoyke, A.M. Popken and V. Böhma (2010). Antioxidant capacity and related parameters of different fruit formulations. LWT -Food Sci. Technol., 43 (6): 992-999.

Nistor, O.V., E. Popa, E. Botez and O.E. Constantin (2010). Researches on the evolution of concentrated fruit juices quality at storage. J. Fac. Food Eng., 84-89

Poiana, M.A., D. Moigradean, D. Raba, L.M. Alda and M. Popa (2010). The effect of longterm frozen storage on the nutraceutical compounds, antioxidant properties and colour indices of different kinds of berries. J. Food, Agric. and Environ., 8 (1): 54 - 58.

Ranganna, S. (1977). Manual of Analysis of Fruit and Vegetable Products, Tata MacGraw Hill Company Ltd, New Delhi.

Rickman, J.C., D.M. Barrett and C.M. Bruhn (2007). Review. Nutritional comparison of fresh, frozen and canned fruits and vegetables. Part 1. Vitamins $\mathrm{C}$ and $\mathrm{B}$ and phenolic compounds. J. Sci. Food and Agric., 87 (6):930-944.

Sahari, M.A., F.M. Boostani and E.Z. Hamidi (2004). Effect of low temperature on the ascorbic acid content and quality characteristics of frozen strawberry. Food Chem., 86 (3): 357-363.

Sapei, L. and L. Hwa (2014). Study on the kinetics of vitamin $\mathrm{C}$ degradation in fresh strawberry juices. Procedia Chem., 9: $62-68$.

Sheraz, M.A., M.F. Khan, S. Ahmed, S.H. Kazi and I. Ahmad (2015). Stability and stabilization of ascorbic acid. A review. Household and Personal Care Today, 10 (3): 22-26.

SI, Analytics (2012). Determination of total titratable acidity in wine and most (EU version).www.labsynergy.com / wp-content / uploads/Titrable-Acidity in Wine and -Most - Eu. 28.2.2012.

Singh, A., B.K. Singh, B.C. Deka, S.K. Sanwal, R.K. Patel and M.R. Verma (2011). The genetic variability, inheritance and interrelationships of ascorbic acid, $\beta$-carotene, phenol and anthocyanin content in strawberry (Fragaria $\times$ ananassa Duch.). Sci. Hort., 129 (1): 86-90.

Skrovankova, S., D. Sumczynski, J. Mlcek, T. Jurikova and J. Sochor (2015). Bioactive compounds and antioxidant activity in different types of berries. Int. J. Mol. Sci., 16 (10): $24673-2470$

Sriwattana, S., Y. Phimolsiripol, I. Pongsirikul, N. Utama-ang, S. Surawang, S. Decharatanangkoon, Y. Chindaluang, J. Senapa, W. Wattanatchariya, S. Angeli and P. Thakeow (2015). Development of a concentrated strawberry beverage fortified with longan seed extract. CMU J. Nat. Sci., 14 (2): $175-188$.

Su, M.S. and J.L. Silva (2006). Antioxidant activity, anthocyanins, and phenolics of rabbiteye blueberry (Vaccinium ashei) byproducts as affected by fermentation. Food Chem., 97 (3): 447-451.

Vranac, A., A. Akagić, F. Gaši, N. Spaho, M. Kurtović and M. Meland (2017). Sensory evaluation of blended cloudy apple juices. $28^{\text {th }}$ Int. Scientific-Expert Conf. Agric. and 
Food Industry, 27-29 September, 2017, Sarajevo, Bosnia and Herzegovina.

Wisal, S., M.A. Mashwani and S. Noor (2014).

Storage studies of strawberry juice with TSS of 7.5 and 20.50 Brix preserved with sodium benzoate and potassium sorbate stored at ambient temperature. Int. J. Basic and Appl. Sci., $14: 36-42$.

Zheng, Y., S.Y. Wang, C.Y. Wang and W. Zheng (2007). Changes in strawberry phenolics, anthocyanins and antioxidant capacity in response to high oxygen treatments. Food Sci. Technol., 40 (1): 49-57.

\section{Cut-back تأثيـــر التخــزين بالتجميـــ عــى جــودة عصيـر الفـراولــة الطازج والمركزبطريقة} فتحي محمد محمد فتحي - محمد رجب عبد المجيد- حسن علي إبراهيم صليحةـ عبدالرحمن محمد سليمان

$$
\text { قسم علوم الأغذية - كلية الزر اعة - جامعة الزقازيق- مصر }
$$

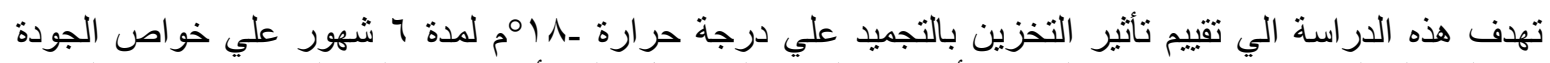

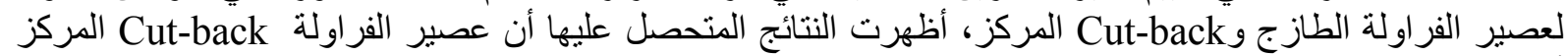

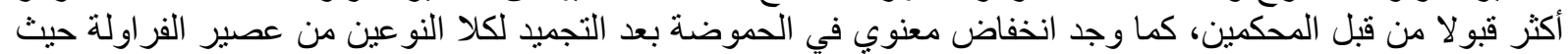

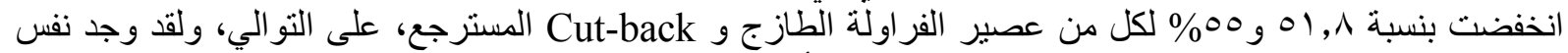

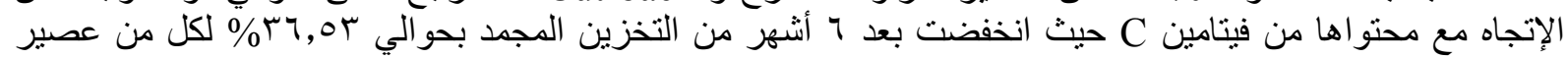

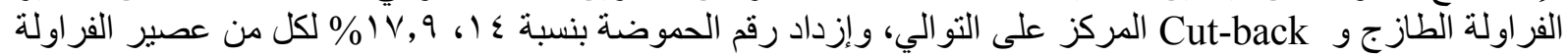

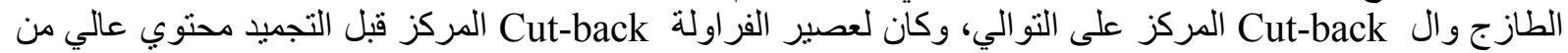

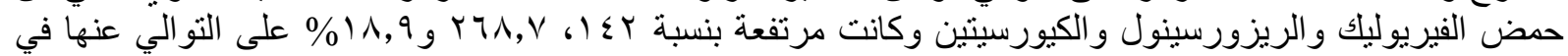

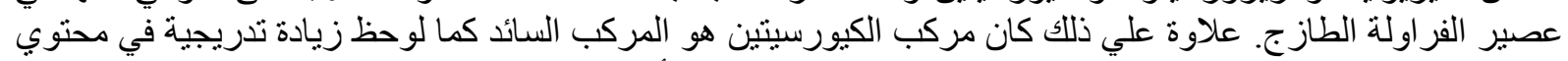

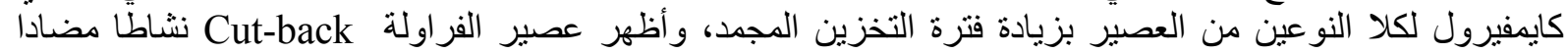

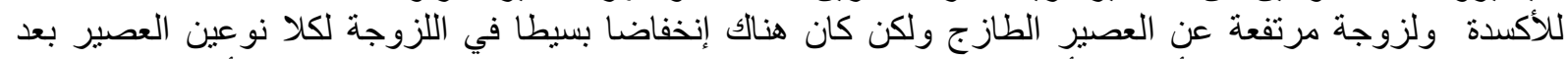

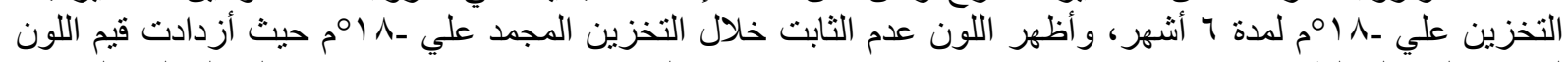

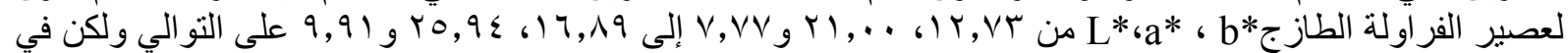

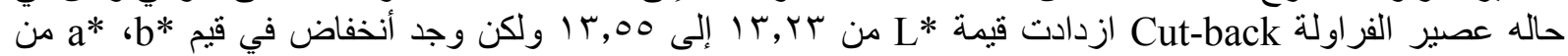

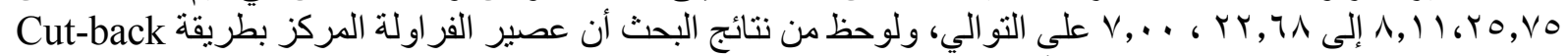
كان الافضل بعد التخزين المجمد لمدة 7 أنثهر. 